\title{
Communication
}

[Comunicação]

\section{Copepod parasites of Curimatella lepidura (Characiformes, Curimatidae) from the Três Marias Reservoir, Brazil}

\author{
[Copépodes parasitos de Curimatella lepidura (Characiformes, Curimatidae) do \\ reservatório de Três Marias, Brasil] \\ M.C. Albuquerque ${ }^{1}$, A.M. Osório ${ }^{2}$, V.E. Thatcher ${ }^{3}$, M.C. Brasil-Sato ${ }^{4 *}$ \\ ${ }^{1}$ Aluna de pós-graduação - UFRRJ - Seropédica, RJ \\ ${ }^{2}$ Aluna de graduação - UFRRJ - Seropédica, RJ \\ ${ }^{3}$ Departamento de Zoologia - Universidade Federal do Paraná - Curitiba, PR \\ ${ }^{4}$ Departamento de Biologia Animal - UFRRJ \\ Caixa Postal 74.539 \\ 23851-970 - Seropédica, RJ
}

\begin{abstract}
Curimatella lepidura Eigenmann and Eigenmann, 1889 (Characiformes, Curimatidae), known by the popular name "manjuba", is abundant in the Três Marias Reservoir, in the São Francisco River Basin (type locality), Brazil (Bristki et al., 1988; Vari, 2003). It reproduces throughout the year and prefers lentic environments (Sato et al., 2003). It is an iliophagous species (Gomes and Verani, 2003) and serves as fodder for larger fish species (macrozoophages) with higher commercial value, such as "piranhas", "pirambebas", "traíras", and "tucunarés".
\end{abstract}

There are reports of Riggia paranensis Szidat, 1948 (Isopoda, Cymothoidea) in Curimata platana (Günther, 1880) and in Cyphocharax gilbert (Quoy \& Gaimard, 1824) (Azevedo et al., 2002). This study presents the first report of the gill parasites of $C$. lepidura, and is accompanied by an evaluation of the parasite indexes, with the aim of verifying whether the gender and size of these fish from the Três Marias Reservoir have a significant influence on these indexes.

A total of 124 specimens of C. lepidura were caught with nets (3 to $16 \mathrm{~cm}$ mesh) from March 2000 to April 2004 in the Três Marias Reservoir, in the upper São Francisco River ( $18^{\circ} 12^{\prime} 51^{\prime}$, $\left.45^{\circ} 15^{\prime} 51^{\prime \prime} \mathrm{W}\right)$, Minas Gerais State. The biometric data, gender and collection site were recorded on necropsy forms. Out of this total, 71 were female, with total length averaging $13.97 \pm 1.23 \mathrm{~cm}$ (ranging from 10.2 to $16.0 \mathrm{~cm}$ ) and total body weight of $38.90 \pm 9.44 \mathrm{~g}$ (17.3 to $75.0 \mathrm{~g}$ ); and 53 were male, with total length of $13.31 \pm 0.91 \mathrm{~cm}(10.3$ to $15.5 \mathrm{~cm})$ and total body weight of $31.70 \pm 7.37$ (10.0 to $46.5 \mathrm{~g}$ ). Voucher specimens of $C$. lepidura were deposited in the collection of the Museu da Universidade de São Paulo - MZUSP 95154.

The gills were removed from the fish, individualized and shaken in flasks containing a small amount of formalin at 1:4000. Then, 5\% formalin was added to fill the flasks to the top and the gills were examined under a stereomicroscope to collect the ectoparasites. The procedures for collection, fixation, conservation, and mounting the copepods on slides for identification were done according to Thatcher (2006). Voucher specimens of the copepods were deposited in the Crustacea collection of the Instituto Nacional de Pesquisas da Amazônia (INPA-CR 1548 a-c and 1549). The statistical analyses applied to the parasite

Recebido em 23 de novembro de 2007

Aceito em 2 de setembro de 2008

*Autor para correspondência (corresponding author)

E-mail: mcbsato@ufrrj.br 
infrapopulations followed Zar (2000) and the parasite indexes followed those conceived by Bush et al. (1997). The statistical tests were only applied to the parasites with prevalence higher than 10\% (Bush et al.,1990) and the level of significance considered in the tests was $\mathrm{P}<0.05$ (Zar, 2000). The following statistical tests were used: Student's t-test to evaluate the differences in total length and body weight between the male and female hosts; the log-likelihood G-test with a $2 \times 2$ contingency table to analyze the prevalence of parasites in relation to the gender of the hosts; Pearson's correlation coefficient $(r)$, with previous angular transformation of the data, to assess the prevalence in relation to the size classes of the hosts, estimated by Sturges' formula; Spearman's rank correlation coefficient $\left(r_{s}\right)$ to verify the possible influence of host size on the parasite intensity and abundance; and the Mann-Whitney $U$-test with normal approximation to evaluate the possible influence of host gender on the parasite abundance and intensity.

A total of 192 ergasilid copepods were found in the gills of $C$. lepidura, of which $174(90.6 \%)$ were Miracetyma etimaruya Malta, 1993 and 18 (9.4\%) were Ergasilus sp. Out of the 124 "manjuba" specimens examined, 60 (48.4\%) were infested by one parasite species, and seven $(5.6 \%)$ by two species of copepod. The parasite parameters of Ergasilus sp. - prevalence (8.9\%), mean intensity (1.63), and mean abundance $(0.15)$ - were lower than those found for $M$. etimaruya $(46.0 \%, 3.05$, and 1.40 , respectively). The female "manjubas" were significantly larger $(t=3.304, \quad \mathrm{P}=0.0013)$ and heavier $(t=4.604$, $\mathrm{P}=0.0001)$ than the males. Nevertheless, the prevalence $\left(X^{2}=0.9718, \quad \mathrm{P}=0.3242 ; \quad r=0.3068\right.$,
$\mathrm{P}=0.46), \quad$ intensity $\quad\left(U^{\prime}=451.00, \quad \mathrm{P}=0.46\right.$; $r s=0.1967, \quad \mathrm{P}=0.14), \quad$ and abundance ( $\left.U^{\prime}=2091.00, \mathrm{P}=0.28 ; r s=0.1466, \mathrm{P}=0.10\right)$ of $M$. etimaruya were not influenced by the total length or gender of the hosts, respectively.

In the upper São Francisco River, "manjuba" is abundant and is an optional food source for larger fish. It is potentially useful from the standpoint of fish farming, because as a primary consumer (iliophagous species), it can produce protein at low cost (Andrade, 1990). However, the spread of copepod parasites to the fish stocks must be avoided by prophylactic handling. Ergasilus spp. have been reported in fish of various families in the upper São Francisco River (Brasil-Sato, 2003) and a careful taxonomic investigation is necessary. There have been descriptions of Miracetyma etimaruya in Curimata cyprinoids (Linnaeus, 1758) from Jamari and Jiparaná Rivers; in Potamorhina latior (Spix, 1829) from Guaporé and Mamoré Rivers; in Psectrogaster essequibensis (Günther, 1864) from Pacaás Novos River; Miracetyma piraya in Pygocentrus nattereri Kner, 1858 from Mamoré River; and Miracetyma kawa in Rhaphiodum vulpinus Reinhardt, 1849 from Momoré, Guaporé, and Jamari Rivers by Malta (1993a, b, c, respectively), Rondônia State, Brazil. Thus, this report expands the geographic distribution of $M$. etimaruya to the São Francisco Basin and also the list of known hosts to include Curimatella lepidura, a representative of the Curimatidae, which is endemic to the São Francisco River.

Keywords: fish, parasites, Ergasilidae, Curimatidae, Ergasilus sp., Miracetyma etimaruya

\section{RESUMO}

Copépodes ergasilídeos coletados nas brânquias de Curimatella lepidura do reservatório de Três Marias, alto rio São Francisco, Minas Gerais, Brasil e identificados como Miracetyma etimaruya e Ergasilus sp., constituem o primeiro registro de parasitos nesse peixe forrageiro e endêmico. A ocorrência foi independente do sexo e do tamanho dos peixes. A distribuição geográfica conhecida das espécies de Miracetyma Malta, 1993, restrita à bacia do rio Amazonas, é ampliada neste estudo para a bacia do rio São Francisco.

Palavras-chave: peixe, parasitismo, Ergasilidae, Curimatidae, Ergasilus sp., Miracetyma etimaruya 


\section{ACKNOWLEDGMENTS}

The authors thank Dr Yoshimi Sato, head of the Três Marias Hydrobiology and Fish Farming Station/CODEVASF, for organizing the collection of the fish specimens and logistics and bibliographic assistance. Also to Dr Osvaldo Takeshi Oyakawa and to Dr. Célio Magalhães for his kindness in receiving the specimens sent for deposit at the MZUSP and INPA-CR, respectivelly. This study received logistics and material support under a working arrangement between CEMIG-GT and CODEVASF/Três Marias and a cooperation agreement between UFRRJ and IBAMA/MG. The first author also received a master scholarship from CAPES.

\section{REFERENCES}

ANDRADE, D.R. Biologia reprodutiva $d a$ manjuba Curimatella lepidura Eigenmann \& Eigenmann, 1889 (Pisces, Curimatidae) da represa de Três Marias, rio São Francisco, $M G$. 1990. 217f. Tese (Doutorado) - Instituto de Ciências Biológicas, Universidade Federal de Minas Gerais, Belo Horizonte.

AZEVEDO, J.S.; THOMÉ, M.P.M.; GOMES DA SILVA, L. et al. Parasitismo de Riggia paranensis (Crustacea, Cymothoidea) em populações de Cyphocharax gilbert (Teleostei, Curimatidae) do norte do estado do Rio de Janeiro. Bol. Inst. Pesca, v.28, p.61-69, 2002.

BRASIL-SATO, M.C. Parasitos de peixes da bacia do São Francisco. In: GODINHO, H.P.; GODINHO, A.L. (Eds). Águas, peixes $e$ pescadores do São Francisco das Minas Gerais. Belo Horizonte: PUC Minas, 2003. p.149-165.

BRITSKI, H.A.; SATO, Y.; ROSA, A.B.S. Manual de identificação de peixes da região de Três Marias. 3. ed. Brasília: CODEVASF, 1988. $115 \mathrm{p}$.

BUSH, A.O.; AHO, J.M.; KENNEDY, C.R. Ecological versus phylogenetic determinants of helminth parasite community richness. Evol. Ecol., v.4, p.1-20, 1990.

BUSH, A.O.; LAFFERTY, J.M.; SHOSTAK, A.W. Parasitology meets ecology on its own terms: Margolis et al. revisited. J. Parasitol., v.83, p.575-583, 1997.

GOMES, J.H.C.; VERANI, J.R. Alimentação de espécies de peixes do reservatório de Três Marias. In: GODINHO, H.P.; GODINHO, A.L. (Eds). Águas, peixes e pescadores do São Francisco das Minas Gerais. Belo Horizonte: PUC Minas, 2003. p.195-227.

MALTA, J.C.O. Miracetyma etimaruya gen. et sp. n. (Copepoda, Poecilostomatoida, Ergasilidae) from freshwater fishes of the Brazilian Amazon. Acta Amaz., v.23, p.49-57, 1993a.

MALTA, J.C.O. Myracetyma piraya sp. nov. (Copepoda, Ergasilidae) das brânquias de Pygocentrus nattereri (KNER, 1860) (Characiformes: Serrasalmidae) da Amazônia Brasileira. Acta Amaz., v.23, p.261-269, 1993b.

MALTA, J.C.O. Miracetyma kawa sp. nov. (Copepoda, Poecilostomatoida, Ergasilidae) dos peixes de água doce da Amazônia brasileira. Acta Amaz., v.23, p.251-259, 1993c.

SATO, Y.; FENERICH-VERANI N.; NUNER, A.P.O.N. et al. Padrões reprodutivos de peixes da bacia do São Francisco. In: GODINHO, H.P.; GODINHO, A.L. (Eds). Águas, peixes e pescadores do São Francisco das Minas Gerais. Belo Horizonte: PUC Minas, 2003. p.229-274.

THATCHER, V.E. Amazon fish parasites. 2.ed. Sofia: Pensoft Publications, 2006. 508p.

VARI, R.P. Family Curimatidae. In: REIS, R.E.; KULLANDER, S.O.; FERRARIS Jr. C.J. (Eds). Checklist of the freshwater fishes of Sul and Central America. Porto Alegre: PUCRS, 2003. $742 \mathrm{p}$.

ZAR. J.H. Bioestatistical Analysis. 3.ed. New Jersey: Prentice-Hall, 2000. 659p. 